Original Article

\title{
PHYTOCHEMICAL ANALYSIS AND IN VITRO STUDIES ON ANTIBACTERIAL, ANTIOXIDANT AND ANTI-INFLAMMATORY ACTIVITIES USING CASUARINA EQUISETIFOLIA BARK EXTRACTS
}

\author{
SARANYA V. T. K. ${ }^{1}$, S. UMA GOWRIE* \\ ${ }^{1}$ Department of Plant Biology and Plant Biotechnology, Ethiraj College for Women, Chennai 600008 \\ Email: umasezhian@gmail.com
}

Received: 22 Aug 2017 Revised and Accepted: 22 Nov 2017

\begin{abstract}
Objective: Casuarina equisetifolia is an important multipurpose exotic forest tree species widely cultivated in the coastal regions of Tamil Nadu that serves as a warehouse of essential secondary metabolites. Identification of these bioactive compounds in this forest tree species might lead to the discovery and development of a new drug to treat various diseases.

Methods: The present study was carried out with an objective to analyse the phytochemicals qualitatively and quantitatively. Gas ChromatographyMass Spectrometry (GC-MS) analysis was performed to evaluate the presence of various volatile compounds. An in vitro antibacterial, antioxidant and anti-inflammatory properties of aqueous and organic solvents of $C$. equisetifolia bark was studied.

Results: The preliminary qualitative screening revealed the presence of alkaloids, glycosides, carbohydrates, proteins, flavonoids, phenols, terpenoids, and tannins. The quantitative analysis revealed the presence of maximum phenols $(71.2 \pm 0.51 \mathrm{mg} / \mathrm{g})$, flavonoids $(35.12 \pm 0.34 \mathrm{mg} / \mathrm{g})$, tannins $(77.59 \pm 0.21)$ and terpenoids $(6 \%)$ in methanolic root extract with respective standards. Several peaks were obtained in the GC-MS analysis which indicates the presence of different secondary metabolites. Antibacterial activity showed a maximum zone of inhibition against Escherichia coli $(23 \pm 0.24$ $\mathrm{mm})$ and Proteus vulgaris $(23 \pm 0.32 \mathrm{~mm})$. The antioxidant potential of various extracts was compared with the standard ascorbic acid. Anti-inflammatory activity was compared with standard diclofenac sodium and the extract showed activities significantly in a dose-dependent manner.
\end{abstract}

Conclusion: From this study, it is revealed that $C$. equisetifolia bark extract possesses efficient antibacterial property, the potential in scavenging free radical, effective antioxidant, powerful anti-inflammatory source that can be employed in the development of a novel drug to treat various diseases.

Keywords: Casuariana equisetifolia, bark, Phytochemicals, Antioxidant, Antibacterial, Anti-inflammatory, GC-MS

(C) 2018 The Authors. Published by Innovare Academic Sciences Pvt Ltd. This is an open-access article under the CC BY license (http://creativecommons.org/licenses/by/4.0/) DOI: http://dx.doi.org/10.22159/ijpps.2018v10i1.22188

\section{INTRODUCTION}

Plants serve as a potential storage of various secondary metabolites (phytochemicals). These phytochemicals covers diverse and important biochemical components, that serves as a raw material for the development of pharmacologically active natural products. Plants still serve as the base for the existence and development of traditional medicine system for thousands of years in India. A study conducted by [1] reports that, the drugs that are developed for the commercial purpose were obtained from higher plants, of which $74 \%$ of drugs were developed with the help of ethnobotanical information. Plant-based drugs have greater scientific and economic significance. Phenols, flavonoids, tannins, terpenoids, alkaloids and steroids are a group of secondary metabolites obtained from plants that have drawn the attention of pharmaceutical industries in recent years [2].

Casuarina equisetifolia Linn. Belongs to the family Casuarinaceae. It is a non-leguminous, woody forest tree which is in symbiotic association with an actinomycete, Frankia. Thus, this association helps in nitrogen fixation and also makes the tree to adapt to varied soil types and extreme environmental stress conditions. $C$. equisetifolia is mainly cultivated in coastal regions to provide fuelwood, protection against shifting dunes, heavy wind blow and in addition it serves as a stable base for agriculture [3,4]. In south India, C. equisetifolia is employed exclusively in agroforestry system. The pulp material of this tree crop is widely used in the paper industries. Other parts of the tree crop like root, bark and cladode which has potent phytochemical constituents are marked as waste material and are used for fuel purpose by local people. This study is an attempt to explore the potential phytoconstituents of one such resource namely bark and its pharmaceutical evaluation.

Presence of high amount of tannin in the bark of $C$. equisetifolia marks its action against toothache traditionally [5]. A study conducted by [6] confirmed the presence of alkaloids, flavonoids, tannins and proteins, which could be responsible for the potent antibacterial and antioxidant property.

The objective of the current study is to evaluate the phytochemicals qualitatively and quantitatively, GC-MS analysis, antibacterial potential, antioxidant and anti-inflammatory ability of the bark extracts using aqueous and organic solvents.

\section{MATERIALS AND METHODS}

\section{Collection of plant material}

The bark samples of Casuarina equisetifolia Linn. Was collected from Nimilenchery, Pondicherry Union territory (Lattitude: 12.10'; Longitude 79.9'), Tamil Nadu. The plant sample was taxonomically identified and authenticated as Casuarina equisetifolia Linn., Casuarinaceae, Ref No: BSI/SRC/5/23/2015/Tech/2012 Botanical Survey of India, Coimbatore.

\section{Chemicals and reagents}

Benzene, chloroform, methanol, ethanol, petroleum ether, folinciocalteu reagent, folin-denis reagent, sodium carbonate, gallic acid, sodium nitrite, aluminium chloride, sodium hydroxide, quercetin, 2,2-diphenyl-1-picryyhydrazl, hydrogen peroxide, ascorbic acid, potassium ferric cyanide, sodium salicylate, sulphuric acid, sodium phosphate.

\section{Preparation of bark extract}

Dried bark samples of $C$. equisetifolia was surface sterilized, cut into small pieces and was finely powdered. Powdered bark samples were extracted using water and organic solvents (Benzene, Chloroform, Methanol and Ethanol) in the ratio $1: 10 \mathrm{w} / \mathrm{v}$, for $48 \mathrm{~h}$, by cold percolation method. The extract was filtered, concentrated and dried and stored at $4{ }^{\circ} \mathrm{C}$ until further use. 


\section{Qualitative phytochemical screening}

Preliminary phytochemicals screening of bark samples were carried out using different solvents (Aqueous, Benzene, Chloroform, Methanol and Ethanol). The qualitative phytochemical analysis was carried out to screen the presence of phenols, alkaloids, flavonoids, terpenoids, carbohydrates, saponins, proteins and amino acids, phlobatannins, glycosides and tannins using standard procedures.

\section{Quantitative analysis}

\section{Estimation of total phenol content}

The total phenolic content in aqueous, ethanol and methanol extracts of $C$. equisetifoila bark was determined by Folin-Ciocalteu reagent (FCR) [7]. To $1 \mathrm{ml}$ of the various extracts, $1 \mathrm{ml}$ of Folin-Ciocalteu reagent was added and the mixture was incubated for $5 \mathrm{~min}$. To this, $10 \mathrm{ml}$ of $7 \%$ $\mathrm{Na}_{2} \mathrm{CO}_{3}$ solution was added and incubated in dark at $23{ }^{\circ} \mathrm{C}$ for $90 \mathrm{~min}$. The absorbance of the mixture was read at $765 \mathrm{~nm}$ against the blank using UV-visible spectrophotometer (UV 1650 Pc, Schimadzu). Gallic acid was used as a standard. The total phenolic content in the extracts was expressed in Gallic acid equivalent (GAE).

\section{Estimation of total flavonoid content}

The total flavonoid content was estimated using aluminium chloride colourimetric method [8]. $0.5 \mathrm{ml}$ of various bark extracts were mixed with $2 \mathrm{ml}$ of solvent and $0.30 \mathrm{ml}$ of $5 \%$ sodium nitrite solution individually. To this solution mixture, $0.3 \mathrm{ml}$ of $10 \% \mathrm{AlCl}_{2}, 2 \mathrm{ml}$ of $1 \mathrm{M}$ sodium hydroxide and $2.8 \mathrm{ml}$ of distilled water was added and incubated at room temperature for $30 \mathrm{~min}$. The absorbance was read at $510 \mathrm{~nm}$ using UV-visible spectrophotometer (UV $1650 \mathrm{Pc}$, Schimadzu). Quercetin was used as the standard for estimation. Total flavonoid concentration was expressed in terms of Quercetin equivalent (mg of QAE/g of extract).

\section{Estimation of tannin}

The total tannin content in aqueous, ethanol and methanol extracts of C. equisetifoila bark was estimated by Folin Denis method [9], with slight modifications. To $1 \mathrm{ml}$ of bark extracts (aqueous, ethanol and methanol), $3 \mathrm{ml}$ of water, $0.5 \mathrm{ml}$ of Folin-Denis reagent and $1.0 \mathrm{ml}$ of $1 \mathrm{~N}$ sodium carbonate solution were added. This mixture was diluted with water. The solution was mixed thoroughly and the absorbance was read at $515 \mathrm{~nm}$. Tannic acid was used as the standard. Total tannin content was expressed as milligrams of tannic acid equivalents per gram of dried sample (mg of TAE/g of extract).

\section{Estimation of total terpenoids}

Total terpenoid content was estimated [10] for ethanol, methanol and aqueous extract of $C$. equisetifolia bark. The crude extract was soaked in $20 \mathrm{ml}$ of $95 \%$ ethanol for $24 \mathrm{~h}$. The filtrate was extracted with petroleum ether $\left(60^{\circ} \mathrm{C}-80^{\circ} \mathrm{C}\right)$. The residue of the extract obtained from the petroleum ether extract was dried and weighed to estimate the total terpenoids.

$$
\text { Terpenoid content }(\%)=\frac{\text { Weight of terpenoid extract }(\mathrm{g})}{\text { Weight of the sample }(\mathrm{g})} \times 100
$$

\section{GC-MS studies}

The methanolic bark extract was subjected to GC-MS (Perkin Elmer, Sophisticated Instrumentation Facility, Vellore Institute of Technology University, Vellore, Tamilnadu) analysis to identify the bioactive compounds. The Clarus $680 \mathrm{GC}$ was used in the analysis that employed a fused silica column, packed with Elite-5MS (5\% biphenyl $95 \%$ dimethylpolysiloxane, $30 \mathrm{~m} \times 0.25 \mathrm{~mm}$ ID $\times 250 \mu \mathrm{m} \mathrm{df).} \mathrm{The}$ components were separated using Helium as a carrier gas, at a constant flow of $1 \mathrm{ml} / \mathrm{min}$. The injector temperature was set at $260^{\circ} \mathrm{C}$ during the chromatographic run. $1 \mu \mathrm{L}$ of the bark extract was injected into the instrument. The oven temperature was as follows: $60^{\circ} \mathrm{C}(2$ min); followed by $300{ }^{\circ} \mathrm{C}$ at the rate of $10^{\circ} \mathrm{C}$ min-1; and $300{ }^{\circ} \mathrm{C}$, where it was held for $6 \mathrm{~min}$. The mass detector conditions were: transfer line temperature $240{ }^{\circ} \mathrm{C}$; ion source temperature $240{ }^{\circ} \mathrm{C}$; and ionization mode electron impact at $70 \mathrm{eV}$, a scan time $0.2 \mathrm{sec}$ and scan interval of $0.1 \mathrm{sec}$. The fragments from 40 to $600 \mathrm{Da}$. The spectrums of the components were compared with the database of the spectrum of known components stored in the GC-MS NIST (2008) library.

\section{Antibacterial activity}

In vitro antibacterial assay using aqueous, ethanolic and methanolic bark extract of $C$. equisetifolia of various concentrations $(25 \mu \mathrm{g}, 50$ $\mu \mathrm{g}, 75 \mu \mathrm{g}, 100 \mu \mathrm{g}$ ) was determined by agar well diffusion method, using Muller Hinton agar medium. The antibacterial efficiency of bark extracts was tested against Escherchia coli, Bacillus subtilis, Staphylococcus aureus, Proteus vulgaris obtained from the Department of Microbiology, Ethiraj College for women, Chennai. Zone of inhibition was observed after incubating the plates at $37^{\circ} \mathrm{C}$ for $24 \mathrm{~h}$. Gentamycin $(100 \mu \mathrm{g})$ was used as positive control and the solvent was used as negative control for the bacterial assay. Triplicates were maintained.

\section{Antioxidant assay}

\section{2,2-diphenyl-1-picrylhydrazyl (DPPH) radical scavenging assay}

The free radical scavenging activity of aqueous, ethanol and methanol bark extract of $C$. equisetifolia was tested using DPPH radical scavenging assay [11]. Four different concentration of bark extracts were prepared $(20 \mu \mathrm{g} / \mathrm{ml}, 40 \mu \mathrm{g} / \mathrm{ml}, 60 \mu \mathrm{g} / \mathrm{ml}, 80 \mu \mathrm{g} / \mathrm{ml}) .2$ $\mathrm{ml}$ aliquot of DPPH solution was added to $0.5 \mathrm{ml}$ of each concentration of various bark extracts. The reaction mixture was incubated at room temperature for $30 \mathrm{~min}$. The absorbance was determined at $517 \mathrm{~nm}$ using UV-visible spectrophotometer (UV 1650 Pc, Schimadzu). Ascorbic acid was used as a standard. Percent inhibition and Inhibitory concentration ( $\mathrm{IC}_{50}$ ) value were calculated. Experiments were performed in triplicates and the average was calculated for each concentration.

$$
\begin{gathered}
\text { DPPH scavenging effect }(\%) \text { or Percent inhibtion } \\
=\mathrm{A} 0-\mathrm{A} 1 / \mathrm{A} 0 \times 100
\end{gathered}
$$

Where $A_{0}$ was the absorbance of the control (blank, without extract) and $A_{1}$ was the absorbance in the presence of the extract.

\section{Hydrogen peroxide scavenging assay}

The ability of bark extracts to scavenge hydrogen peroxide was determined spectrometrically [12]. Different concentrations (20 $\mu \mathrm{g} / \mathrm{ml}, 40 \mu \mathrm{g} / \mathrm{ml}, 60 \mu \mathrm{g} / \mathrm{ml}, 80 \mu \mathrm{g} / \mathrm{ml}$ ) of various bark extracts were added to $0.6 \mathrm{ml}$ of $2 \mathrm{mmol} / \mathrm{l}$ of hydrogen peroxide solution prepared in phosphate buffer ( $\mathrm{pH}=7.4)$. Absorbance was measured at $230 \mathrm{~nm}$ against blank solution (phosphate buffer) using UV-visible spectrophotometer (UV 1650 Pc, Schimadzu) and was compared with the standard Ascorbic acid. Experiments were performed in triplicates.

Hydrogen peroxide scavenging effect $(\%)=\mathrm{Ac}-\mathrm{Ao} / \mathrm{Ac} \times 100$

Where $A_{0}$ was the absorbance of the control (blank, without extract) and $A_{1}$ was the absorbance in the presence of the extract.

\section{Reducing power assay}

The reducing power of aqueous, ethanol and methanol extract of $C$. equisetifolia bark were determined [13]. Various concentrations (20 $\mu \mathrm{g} / \mathrm{ml}, 40 \mu \mathrm{g} / \mathrm{ml}, 60 \mu \mathrm{g} / \mathrm{ml}, 80 \mu \mathrm{g} / \mathrm{ml}$ ) of corresponding solvent extracts of $C$. equisetifolia bark, were mixed with $0.2 \mathrm{M}$ phosphate buffer $(2.5 \mathrm{ml})$ and $1 \%$ potassium ferricyanide $(2.5 \mathrm{ml})$. The reaction mixture was incubated at $50{ }^{\circ} \mathrm{C}$ for $20 \mathrm{~min}$. After cooling, $2.5 \mathrm{ml}$ of $10 \%$ trichloroacetic acid was added to the reaction mixture and centrifuged at $3000 \mathrm{rpm}$ for $10 \mathrm{~min}$. The supernatant $(2.5 \mathrm{ml})$ was collected and mixed with freshly prepared $0.1 \% \mathrm{FeCl}_{3}(0.5 \mathrm{ml})$.

The absorbance was measured at $700 \mathrm{~nm}$ using UV-visible spectrophotometer (UV 1650 Pc, Schimadzu). Ascorbic acid was used as a reference compound. Experiments were performed in triplicates.

$$
\text { Reducing power assay }(\%)=\frac{\text { Control OD }- \text { Test OD }}{\text { Control OD }} \times 100
$$

\section{Hydroxyl radical scavenging assay}

The hydroxyl radical scavenging assay experiment was carried out using standard method [14]. The reaction mixture was prepared using $1 \mathrm{ml} \mathrm{FeSO}_{4}(1.5 \mathrm{mmol}), 0.7 \mathrm{ml}$ hydrogen peroxide $(6 \mathrm{mmol})$, $0.3 \mathrm{ml}$ sodium salicylate $(20 \mathrm{mmol})$. Different concentrations $(20$ 
$\mu \mathrm{g} / \mathrm{ml}, 40 \mu \mathrm{g} / \mathrm{ml}, 60 \mu \mathrm{g} / \mathrm{ml}, 80 \mu \mathrm{g} / \mathrm{ml}$ ) of various bark extracts were added to $3 \mathrm{ml}$ of reaction mixture. After incubation for $1 \mathrm{~h}$ at $37^{\circ} \mathrm{C}$, the absorbance of the hydroxylated salicylate complex was measured at $562 \mathrm{~nm}$ using UV-visible spectrophotometer (UV 1650 Pc, Schimadzu). Ascorbic acid was used as the standard. Experiments were performed in triplicates.

$$
\text { Per cent inhibtion }=\mathrm{A} 0-\mathrm{A} 1 / \mathrm{A} 0 \times 100
$$

Where $A_{0}$ was the absorbance of the control (blank, without extract) and $A_{1}$ was the absorbance in the presence of the extract.

\section{Total antioxidant capacity assay}

The total antioxidant capacity assay of aqueous extract, ethanol extract and methanol extracts of $C$. equisetifolia bark were determined by a standard method [15]. Different concentrations of $C$. equisetifolia bark extracts $(20 \mu \mathrm{g} / \mathrm{ml}, 40 \mu \mathrm{g} / \mathrm{ml}, 60 \mu \mathrm{g} / \mathrm{ml}$, $80 \mu \mathrm{g} / \mathrm{ml})$ were added to $1.0 \mathrm{ml}$ of the reagent solution $(0.6 \mathrm{M}$ sulphuric acid, $28 \mathrm{mmol}$ sodium phosphate and $4 \mathrm{mmol}$ ammonium molybdate. The reaction mixture was incubated at $95^{\circ} \mathrm{C}$ for $90 \mathrm{~min}$. After cooling, the absorbance was measured at $695 \mathrm{~nm}$ against a blank using UV-visible spectrophotometer (UV 1650 Pc, Schimadzu). Ascorbic acid was used as a standard. Experiments were performed in triplicates.

$$
\text { Per cent inhibtion }=\mathrm{A} 0-\mathrm{A} 1 / \mathrm{A} 0 \times 100
$$

Where $A_{0}$ was the absorbance of the control (blank, without extract) and $A_{1}$ was the absorbance in the presence of the extract.

\section{In vitro anti-inflammatory activity}

Protein denaturation ability of various solvents extracts of $C$. equisetifolia was studied using inhibition of albumin denaturation technique [16]. Various concentration of test solution $(20 \mu \mathrm{g}, 40 \mu \mathrm{g}$, $60 \mu \mathrm{g}, 80 \mu \mathrm{g}$ ) was prepared using different solvents. The reaction mixture consists of $100 \mu \mathrm{l}$ of different concentrations and $500 \mu \mathrm{l}$ of $1 \%$ of aqueous bovine albumin fraction.

The reaction mixture was incubated at $37^{\circ} \mathrm{C}$ for $10 \mathrm{~min}$ and then heated at $51{ }^{\circ} \mathrm{C}$ for $20 \mathrm{~min}$. The turbidity was measured at $660 \mathrm{~nm}$ using UV-visible spectrophotometer (UV 1650 Pc, Schimadzu) after cooling and was compared with the reference compound Diclofenac sodium. Experiments were performed in triplicates.

Percent inhibition of protein denaturation was calculated using the formula:

$$
\text { Per cent Inhibition }=\frac{\text { Control OD }- \text { Test OD }}{\text { Control OD }} \times 100
$$

\section{Statistical analysis}

The experiments were performed in triplicates. Data was represented as mean \pm SD.

\section{RESULTS AND DISCUSSION \\ Qualitative phytochemical screening}

Preliminary qualitative phytochemical screening of aqueous and organic solvent extracts of Casuarina equisetifolia bark showed the presence of varied phytochemicals (table 1). All the extracts showed the presence of proteins and phenols. Aqueous, ethanol and methanol extracts showed the presence of alkaloids, glycosides, carbohydrates, flavonoids and tannins. Benzene and chloroform extracts showed the presence of proteins, phenols and terpenoids. Ethanolic and methanolic extract revealed the presence of all the phytochemicals. The observations from the present study can be rationalized in terms of the polarity of the compounds being extracted by each solvent. The presence of phytochemicals such as alkaloids, flavonoids, carbohydrates, and tannins from the aqueous and methanolic extracts of Casuarina equisetifolia bark has been reported by [17].

Phytochemicals are plant derivatives that protect the plants from varied stress conditions and pathogens. Though these phytochemicals are not highlighted as essential nutrients, it has become a key constituent in the pharmaceutical industry for the development of novel drugs that has a minimum or no side effects. Plant phenolic compounds are responsible for antimicrobial activity and antioxidant activity since it reduces lipid peroxidation [18]. Flavonoids possess a functional hydroxyl group that mediates the antioxidant effect by scavenging free radical or by chelating the metal ions [19] and it is also responsible for the modification of topography of microbial cell wall, thus functioning as an antimicrobial agent [20]. Tannin is a polyphenolic compound and it has been evaluated that polyphenolic compounds acts as a potent source of antimicrobial, antioxidant [21], anti-inflammatory [22] and analgesic agent. It has been documented that the plants with antimicrobial and free radical scavenging properties accelerate wound healing by enhancing the process of re-epithelialization and contraction of the wound [23]. The medicinal value of a plant is also dependent on other phytochemicals like, alkaloids, carbohydrates, glycosides and proteins which produces definite physiological actions on the human body.

In the qualitative phytochemical screening, maximum solubility of phytochemicals was observed in aqueous, ethanol and methanol bark extracts. Thus, these three extracts were carried on for further quantification and in vitro studies.

Table: 1 Phytochemical analysis of different extracts of $C$. equisetifolia bark

\begin{tabular}{llllll}
\hline S. No. & Phytochemicals & Aqueous & Benzene & Chloroform & Ethanol \\
\hline 1 & Alkaloids & + & - & - & Methanol \\
2 & Glycosides & + & - & - & + \\
3 & Carbohydrates & + & + & + & + \\
4 & Protiens & + & + & + & + \\
5 & Phenols & + & + & - & + \\
6 & Flavonoids & + & + & + & + \\
7 & Tannins & + & + & + & + \\
8 & Terpenoids & + & + & + \\
+
\end{tabular}

\footnotetext{
+: Presence.-: Absence
}

\section{Quantitative phytochemical analysis}

The total phenolic content in aqueous, ethanol and methanolic extracts of Casuarina equisetifolia bark was determined by Folinciocalteu method and was expressed in Gallic acid equivalent (Standard Curve equation $\mathrm{y}=0.175 \mathrm{x}-0.118, \mathrm{R}^{2}=0.995$ ). Among the three extracts, methanol extract contained maximum phenol content $(71.2 \pm 0.12 \mathrm{mgGAE} / \mathrm{g}$ of extract), followed by ethanol extract $(66.8 \pm 0.17 \mathrm{mg} \mathrm{GAE} / \mathrm{g}$ of extract) and aqueous extract $(43.2 \pm 0.21 \mathrm{mg}$ $\mathrm{GAE} / \mathrm{g}$ of extract). (fig. 1a) The total flavonoid content in aqueous, ethanol and methanolic extracts of Casuarina equisetifolia bark was determined by the aluminium chloride colourimetric method and was expressed in Quercetin equivalent (Standard Curve equation y = $\left.0.013 x-0.161, R^{2}=0.990\right)$. Among the three extracts, methanol extract contained maximum flavonoids content $(35.12 \pm 0.18 \mathrm{mg}$ of QE/g of extract), followed by ethanol extract $(32.4 \pm 0.31 \mathrm{mg}$ of $\mathrm{QE} / \mathrm{g}$ of extract) and aqueous extract $(27.86 \pm 0.23 \mathrm{mg}$ of $\mathrm{QE} / \mathrm{g}$ of extract). (fig. 1a). The total tannin content was calculated using standard curve of Tannic acid $(y=0.003 x-0.007$ $\mathrm{R}^{2}=0.994$ ) and expressed in Tannic acid equivalents/g of extract. 
Among the various solvents used methanolic extract revealed the highest tannin content of $77.59 \pm 0.27 \mathrm{mg}$ TAE$/ \mathrm{g}$ of extract followed by ethanol and aqueous extracts with $70.45 \pm 0.26$ and $22.29 \pm 0.19$ $\mathrm{mg} \mathrm{TAE} / \mathrm{g}$ of extract respectively (fig. 1a).

The methanol root extracts showed maximum terpenoid content $(6 \%)$ followed by ethanol extract (5.1\%) and aqueous extract $(2.9 \%)$ (fig. 1b).

Phenolic compounds are the most abundant secondary metabolite group which is very important for the defence mechanism of plants. Phytochemical compounds like phenol, flavonoids and tannins posses efficient antibacterial property [24]. Epidemiological studies have proved positive effect of plant phenolic compounds on human health that are capable of inhibiting free radicals and hence can retard the aging process [25]. Polyphenolic compounds like tannins and flavonoids inhibits the initial process of inflammation and thus acts as anti-inflammatory agents [26].

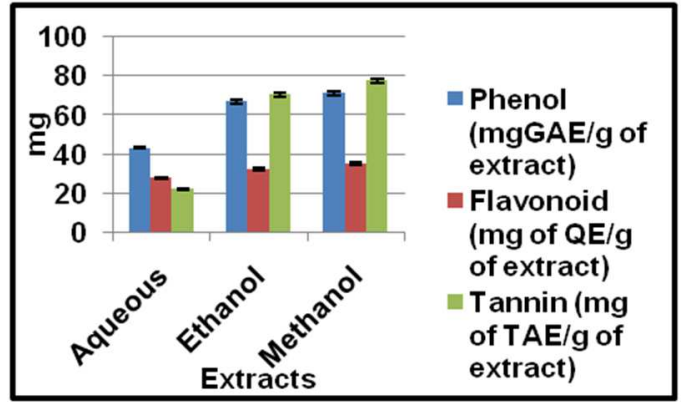

Fig. 1(a): Quantitative analysis (total phenol, flavonoid and tannin) data presented are the means of three replicates

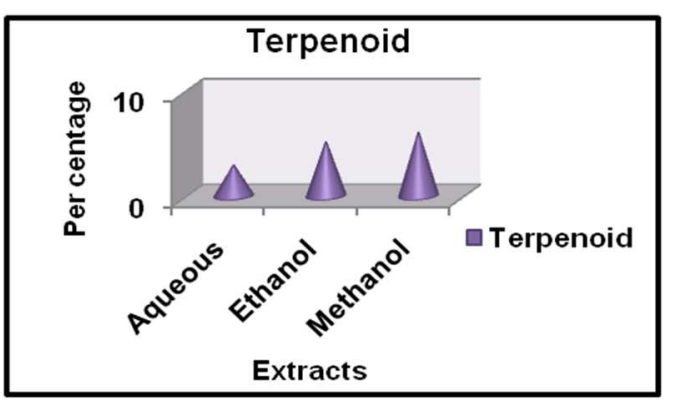

Fig. 1(b): Quantitative analysis-Total Terpenoid Values are expressed as mean of three replicates

\section{GC-MS analysis}

In the present study, methanolic bark extract of Casuarina equisetifolia showed significant bioactivities, hence Gas chromatography-mass spectroscopy analysis (fig. 2) was carried out in methanolic crude extracts of the bark. The peaks in the chromatogram were compared with the NIST database GC-MS library to identify the bioactive compounds.

The chromatogram revealed the presence of trihydroxy bezoic acid, isosorbide dinitrate, 1,2 benzenedicarboxylic acid, mono(2ethylhexyl) ester, di-n-decylsulfone, sulfurous acid, decyl 2-propyl ester, silane, 1,4-phenylenebis, octadecane, 9-ethyl-9-heptyl, cyclotrisiloxane, hexamethyl.

Among the identified compounds, trihydroxybenzoic acid is a phenolic compound (gallic acid), which is a potent radical scavenger. This compound has the therapeutic effect to treat diseases like cancer, neurodegenerative disorder and aging [27-28] which is caused due to oxidative stress. Isosorbide dinitrate comes under nitrate group, which helps to treat congestive heart failure, suppress inflammation and oesophageal spam [29]. 1,2 benzene dicarboxylic acid, mono(2-ethylhexyl) ester is a phthalates group, which is an effective source to suppress the oxidative stress of the cell [30].

Octadecane, 9-ethyl-9-heptyl is a lipid compound that degrades hydrocarbons of the cell wall and helps in antimicrobial activity, thus also serves as a potential antioxidant. Cyclotrisiloxane hexamethyl is a cyclic phenolic compound that plays a significant role in free radical scavenging. The better antioxidant property of the compound is mainly due to the high degree of unsaturation of the cyclic compound than the- $\mathrm{COH}=\mathrm{COH}$-enediol group present in the standard ascorbic acid [31].

\section{Antibacterial activity}

The results indicated that the bark extracts of $C$. equisetifolia showed varied degrees of antibacterial activity at different concentration against different bacterial pathogens. The maximum zone of inhibition was seen at a $100 \mu \mathrm{g}$ concentration of methanolic extract against Escherichia coli $(23 \pm 0.24 \mathrm{~mm})$ and ethanolic extract against Proteus vulgaris $(23 \pm 0.32 \mathrm{~mm})$. Aqueous bark extract showed a maximum zone of inhibition against Escherichia coli with $20.47 \pm 0.3$ mm. (fig. 3).

The study conducted by [32] recorded that the methanolic bark extract of Casuarina equisetifolia showed a maximum zone of inhibition at $10 \mathrm{mg} /$ disc against gram-negative bacteria, E. coli $(35 \pm 0.22 \mathrm{~mm})$. Variation in the zone of inhibition may be correlated to the polarity of the solvent and concentration of the extracts. The synergistic effect of phytochemicals also plays a major role in the antimicrobial activity.

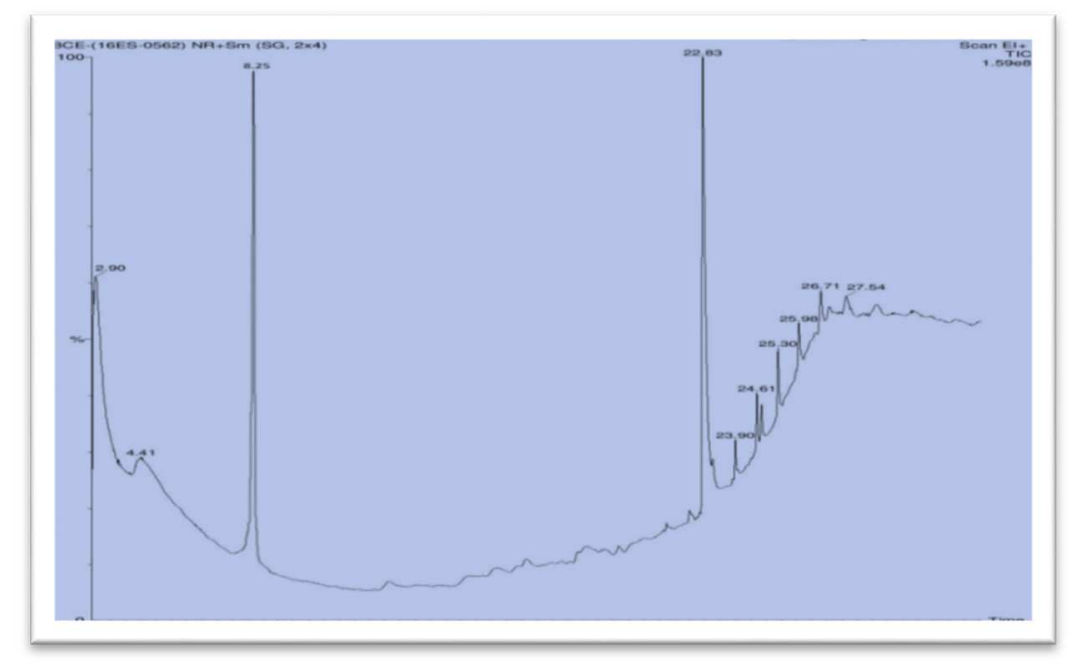

Fig. 2: GC-MS chromatogram of a methanolic extract of $C$. equisetifolia 
The antimicrobial ability of phenolic compounds are based on its potential to penetrate the cell membrane by altering the cell permeability thereby inactivating the cellular enzymes [33]. Flavonoids are synthesized by the plants in response to the microbial infection which could be the reason for potential in vitro antibacterial assay. Flavonoids are found to form a complex with a soluble extracellular protein of bacterial cell wall, thereby destructing the topography leading to the death of the cell [34].
Tannin serves as a potential antibacterial agent because of its ability to bind with proline-rich protein that interferes with the protein production [35].

The lipophilic nature of terpenoids disturbs the membrane-bound protein of bacterial cell wall, increase the permeability of the bacterial cell, which in turn influences the ion transport process and also inhibit respiration that ultimately results in cell death.

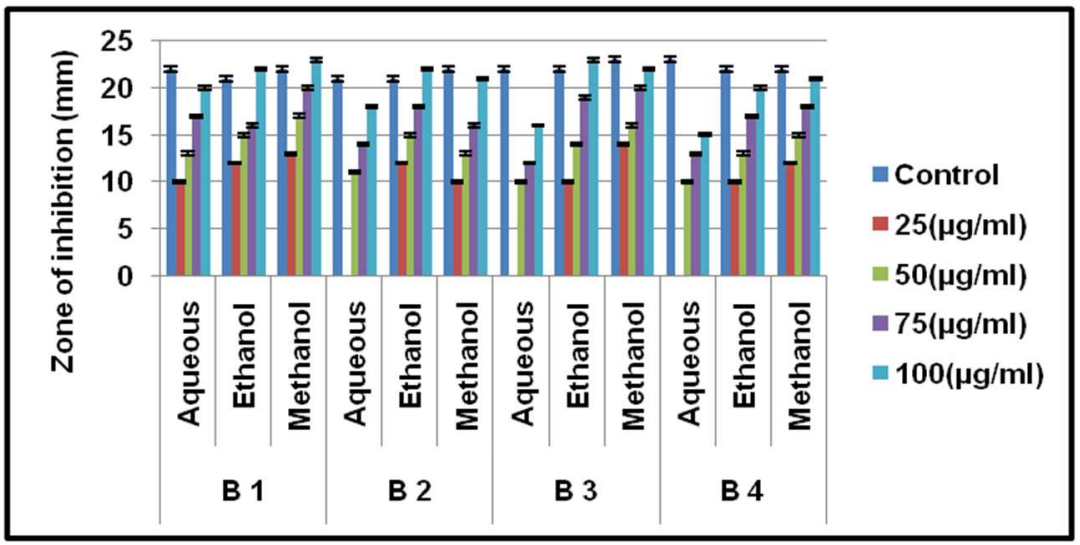

Fig. 3: Antibacterial activity of Casuarina equisetifolia bark extracts against different bacterial pathogens. Data presented are the means of three replicates. Values are expressed as mean \pm SD of three replicates, B1-Escherichia coli B2-Bacillus subtilis, B3-Proteus vulgaris B4Staphylococcus aureus

\section{Antioxidant activity}

\section{DPPH radical scavenging assay}

DPPH radical scavenging assay estimates the ability of the extract to donate Hydrogen or to scavenge the free radical. The methanol extract showed percent maximum inhibition at $80 \mu \mathrm{g}$ concentration $(91.82 \pm 0.93)$ followed by ethanol extract $(89.55 \pm 0.75)$ and aqueous extracts $(88.19 \pm 0.63)$ with IC 50 value of $49.15 \pm 0.64 \mu \mathrm{g} / \mathrm{ml}$, $51.33 \pm 0.86 \mu \mathrm{g} / \mathrm{ml}$ and $54.01 \pm 0.28 \mu \mathrm{g} / \mathrm{ml}$ respectively.

The DPPH activity of standard ascorbic acid showed maximum percent inhibition of $96.34 \pm 0.82$ at $80 \mu \mathrm{g}$ concentration with IC $50 v a l u e$ of $39.22 \mu \mathrm{g} / \mathrm{ml}$. Lower $\mathrm{IC}_{50}$ value indicates greater antioxidant activity (fig. 4).

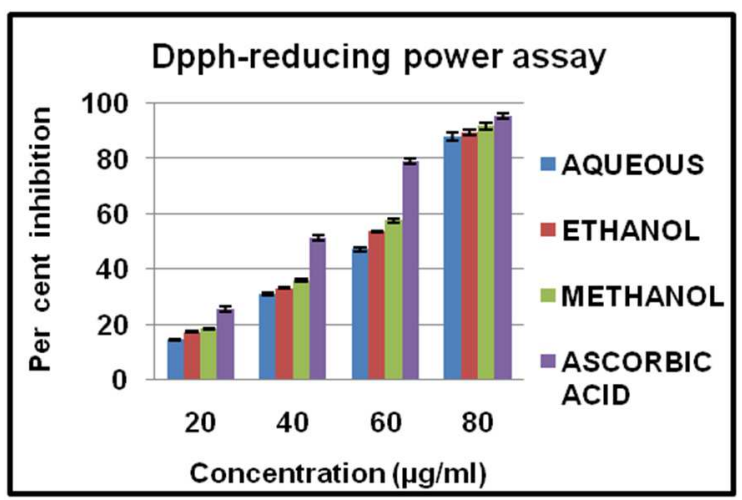

Fig. 4: 2,2-diphenyl-1-picrylhydrazyl (DPPH) free radical scavenging activity of $C$. equisetifolia bark extracts. Data presented are the means of three replicates, values are expressed as mean $\pm \mathrm{SD}$ of three replicates

\section{Hydrogen peroxide scavenging assay}

Hydrogen peroxide has the ability to degrade hemeprotein and release $\mathrm{Fe}$ ions thus, supporting the scavenging activity. The methanol bark extract showed percent maximum inhibition at $80 \mu \mathrm{g}$ concentration (62.90 \pm 0.73$)$ followed by ethanol extract $(57.19 \pm 0.68)$ and aqueous extracts $(50.47 \pm 0.23))$, with IC 50 value of $58.47 \pm 0.63 \mu \mathrm{g} / \mathrm{ml}, 65.34 \pm 0.47 \mu \mathrm{g} / \mathrm{ml}$ and $75.02 \pm 0.85 \mu \mathrm{g} / \mathrm{ml}$ respectively. Maximum percent inhibition and $\mathrm{IC}_{50}$ value indicate, methanolic bark extract as an efficient scavenger. The $\mathrm{IC}_{50}$ value of Standard Ascorbic acid was $44.56 \pm 0.15 \mu \mathrm{g} / \mathrm{ml}$ with percent inhibition of $89.2 \pm 0.76$ (fig. 5).

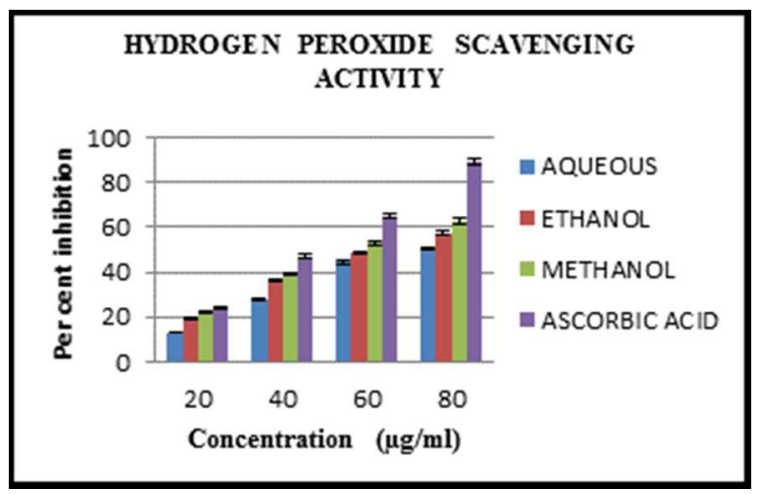

Fig. 5: Hydrogen peroxide scavenging activity of $C$. equisetifolia bark extracts. Data presented are the means of three replicates. Values are expressed as mean $\pm S D$ of three replicates

\section{Reducing power assay}

In the reducing power assay, $\mathrm{Fe}^{3+}$ complex (Ferric cyanide) is reduced to ferrous, with the help of reductones present in the extract. There was an increase in reducing power with an increase in the concentration of aqueous, ethanol and methanolic bark extracts of $C$. equisetifolia. (fig. 6). The methanol extract showed percent maximum inhibition at $80 \mu \mathrm{g}$ concentration $(79.81 \pm 0.74)$ followed by ethanol extract $(75.58 \pm 0.54)$ and aqueous extracts $(69.95 \pm 0.62)$ respectively, with IC 50 value of $49.09 \pm 0.85 \mu \mathrm{g} / \mathrm{ml}, 52.78 \pm 0.42 \mu \mathrm{g} / \mathrm{ml}$ and $59.13 \pm 0.19 \mu \mathrm{g} / \mathrm{ml}$ respectively. The reducing power of standard ascorbic acid showed maximum percent inhibition of $82.16 \pm 0.15$ (IC 50 value of $47.27 \pm 0.31 \mu \mathrm{g} / \mathrm{ml}$ ) at $80 \mu \mathrm{g}$ concentration. 


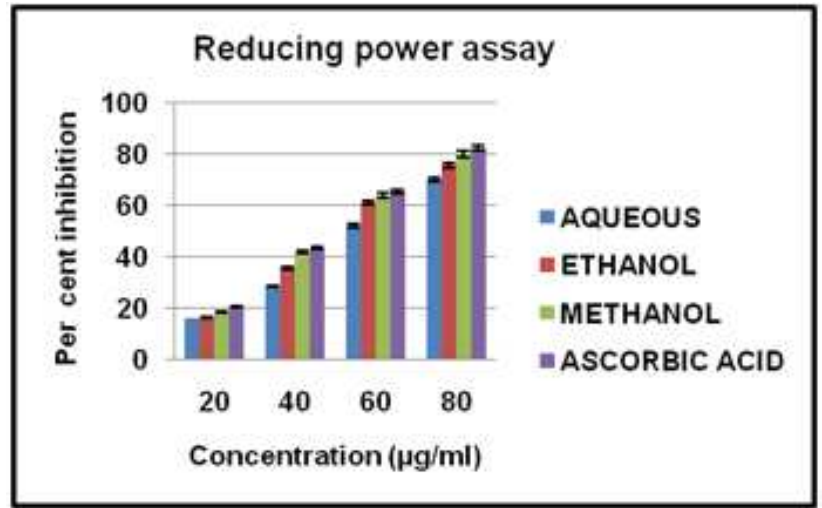

Fig. 6: Reducing power assay of $C$. equisetifolia bark extracts. Data presented are the means of three replicates. Values are expressed as mean $\pm S D$ of three replicates

\section{Hydroxyl radical scavenging assay}

Hydroxyl radical is the most reactive oxygen centered species and causes severe damage to adjacent biomolecule. The methanol extract showed percent maximum reducing ability at $80 \mu \mathrm{g}$ concentration $(78.75 \pm 0.29)$ followed by ethanol extract $(72.08 \pm 0.06)$ and aqueous extract $(60.83 \pm 0.94)$ with IC 50 value of $50.01 \pm 0.37 \mu \mathrm{g} / \mathrm{ml}, \quad 55.51 \pm 0.15 \mu \mathrm{g} / \mathrm{ml}$ and $63.91 \pm 0.68 \mu \mathrm{g} / \mathrm{ml}$ respectively. The reducing power activity of standard ascorbic acid showed maximum percent inhibition of $(82.08 \pm 0.82)$ at $80 \mu \mathrm{g}$ concentration with $\mathrm{IC}_{50}$ value of $47.54 \pm 0.82 \mu \mathrm{g} / \mathrm{ml}$ (fig. 7).

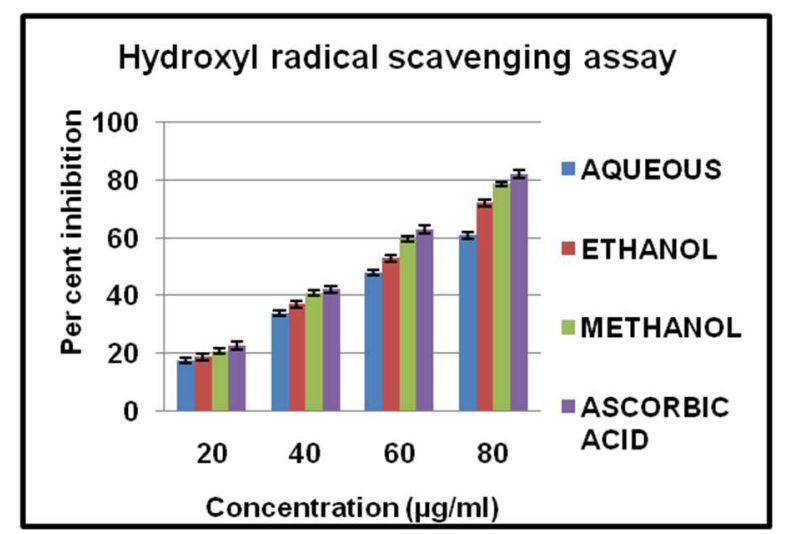

Fig. 7: Hydroxyl radical scavenging assay of $C$. equisetifolia bark extracts. Data presented are the means of three replicates.

Values are expressed as mean \pm SD of three replicates

\section{Total antioxidant capacity assay}

The methanol extract showed percent maximum reducing ability at $80 \mu \mathrm{g}$ concentration $(83.43 \pm 0.47)$ followed by ethanol extract $(77.18 \pm 0.32)$ and aqueous extract $(69.37 \pm 0.28)$ with IC 50 value of $47.89 \pm 0.36 \mu \mathrm{g} / \mathrm{ml}$, $51.61 \pm 0.09 \mu \mathrm{g} / \mathrm{ml}$ and $57.22 \pm 0.13 \mu \mathrm{g} / \mathrm{ml}$ respectively. The reducing power activity of standard ascorbic acid showed maximum percent inhibition of $86.87 \pm 0.83$ at an $80 \mu$ g concentration with IC $_{50}$ value of $45.71 \pm 0.59 \mu \mathrm{g} / \mathrm{ml}$ (fig. 8).

The study of [36], reported that the stem bark of $C$. equisetifolia exhibited potent radical scavenging and reducing power effect. But in the study conducted by [37] reported lower DPPH scavenging activity by catechin (compound isolated from bark).

Antioxidants are substances that significantly delay or prevent the oxidation of an oxidizable substrate when present in low concentrations compared to the substrate [38]. The results obtained in this investigation revealed that all the extracts are free radical scavengers. However, the methanolic extract showed the highest scavenging activity which could be due to the high phenol content.

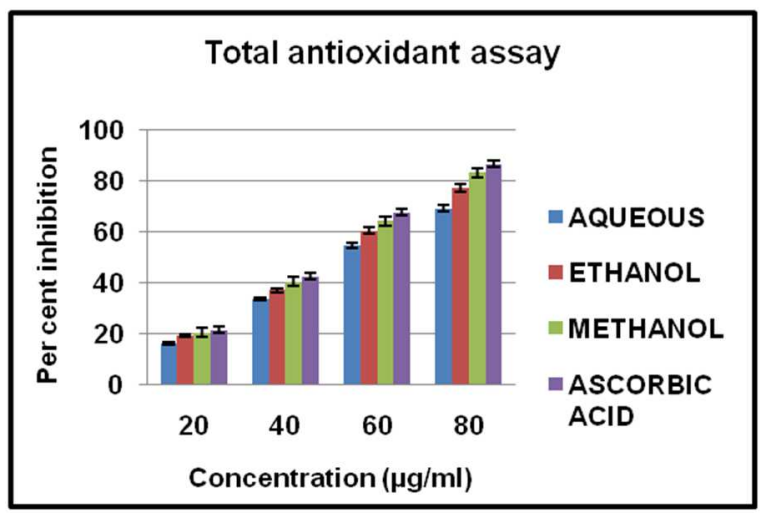

Fig. 8: Total antioxidant activity of $C$. equisetifolia bark extracts, data presented are the means of three replicates. Values are expressed as mean $\pm S D$ of three replicates

Phenols acts as an efficient antioxidant or free radical terminators by donating hydrogen to radicals and breaks the lipid oxidation reaction at the initiation step [39]. Flavonoid compounds have been considered as potential antioxidants because of its ability to terminate radical free species and by upregulating or protecting antioxidant defence [40]. Flavonoids also inhibit LDL (Low-Density Lipoprotien) cholesterol oxidation which in turn scavenges free radicals [41].

Tannin are high molecular weight phenolic compounds that function as both primary and secondary antioxidants [42]. The ability of tannin to chelate metal ion [43] retards the oxidation process. The antioxidant property is attributed to tannin because of its potency to inhibit cyclooxygenase that leads to lipid peroxidation [44].

Terpenoids have the ability to quench the singlet oxygen and to transfer hydrogen or electron that proves it to be a potential antioxidant [45].

\section{Anti-inflammatory assay}

The anti-inflammatory assay was carried out using different concentrations $(20,40,60,80 \mu \mathrm{g} / \mathrm{ml})$ of Casuarina equisetifolia bark extracts. Inhibition of thermally induced protein (albumin) denaturation was based on the concentration of different extracts. The methanol extract showed maximum percent inhibition $(87.05 \pm 0.42)$ when compared to ethanol extract $(83.52 \pm 0.62)$ and aqueous extract $(70.29 \pm 0.14)$ with IC 50 value of $42.99 \pm 0.53 \mu \mathrm{g} / \mathrm{ml}$, $45.94 \pm 0.42 \mu \mathrm{g} / \mathrm{ml}$ and $54.48 \pm 0.31 \mu \mathrm{g} / \mathrm{ml}$ respectively. The antiinflammatory activity of standard diclofenac sodium showed maximum percent inhibition of $92.35 \pm 0.7$ at $80 \mu \mathrm{g}$ concentration with IC $_{50}$ value of $40.80 \pm 0.47 \mu \mathrm{g} / \mathrm{ml}$ (fig. 9).

A study conducted by [46] in evaluating the clinical efficacy of Casuarina equisetifolia bark extract in comparison with the standard, benzoyl peroxide, proved to cure papules, pustules and nodulocystic acne caused by acute inflammation.

The result clearly indicates that the phytoconstituents of extracts have the ability to reduce the synthesis of mediators that are responsible for the development of inflammation. The preliminary phytochemical screening showed the presence of phenols, flavonoids, tannins and terpenoids. This compound has greater potential to inhibit serotonin, leukocyte migration and histamine [47].

Flavonoids are observed to act as a potential anti-inflammatory material in both proliferative phase and exudative phase of inflammation, which may be attributed due to its ability to inhibit histamine, cytokine, and prostaglandin and leukotriene release [26, 48 ] and proves that phenolic compounds, flavonoids can be used in the treatment against various inflammatory disorders $[49, \mathrm{~S} 50]$. 


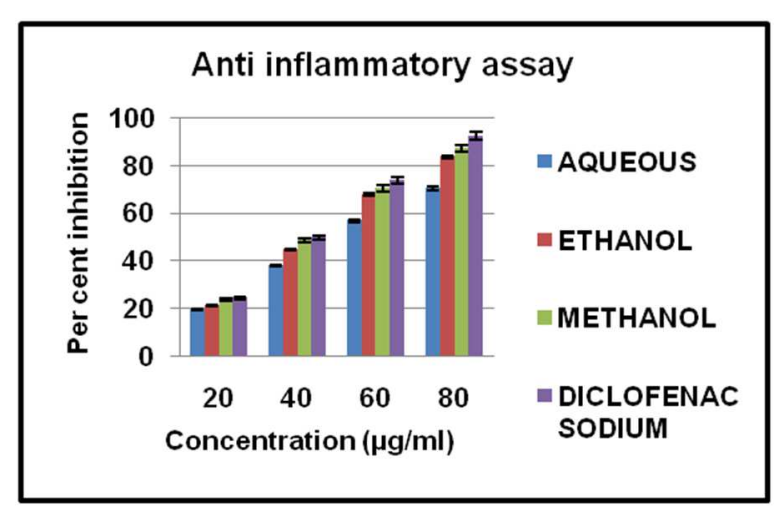

Fig. 9: Anti-inflammatory assay of $C$. equisetifolia bark extracts. Data presented are the means of three replicates. Values are expressed as mean $\pm S D$ of three replicates

\section{CONCLUSION}

The current research work concludes that $C$. equisetifolia bark has a wide pharmacological spectrum, as the plant shows the presence of several secondary metabolites like phenols, flavonoids, tannins and terpenoids in crude extracts, which are responsible for the varied medicinal property. The bioactivity of the secondary metabolites was based on the polarity of the solvents used in the study. The methanolic extract of bark was found to be very efficient antibacterial, antioxidant and anti-inflammatory agent, which may be due to the consortium effect of these secondary metabolites along with the volatile compounds of GC-MS anlaysis. Therefore more evaluation on $C$. equisetifolia bark is being carried out to formulate the chemical constituents that could be employed in drug discovery leading to the application in the biomedical field.

\section{ACKNOWLEDGEMENT}

The authors thank Mrs. Prema Sampathkumar, Associate Professor and Head, the Faculty members and supporting staff of the Department of Plant Biology and Plant Biotechnology, Dr. Mrs. A. Nirmala, Principal, Ethiraj College for Women, (Autonomous), Chennai-600 008, for their valuable support and encouragement throughout the entire period of research. We would also like to express our thanks for the facilities extended by the Central Instrumentation Centre of Ethiraj College for Women.

\section{AUTHORS CONTRIBUTIONS}

All the authors contributed equally

\section{CONFLICT OF INTERESTS}

The authors declare that they have no conflict of interest in the publication

\section{REFERENCES}

1. Fransworth NR. In bioactive compounds from plants. John and Wiley Co; 1990.

2. Sukanya SL, Sudisha J, Hariprasad P, Niranjana SR, Prakash HS, Fathima SK. Antimicrobial activity of leaf extracts of Indian medicinal plants against clinical and phytopathogenic bacteria. Afr J Biotechnol 2009;8:6677-82.

3. Turnbull JW. The use of Casuarina equisetifolia for protection forests in China. In: Midgley SJ, Turnbull JW, Johnston RD. eds. Casuarina Ecology, Management and Utilization. Proceedings of the. $1^{\text {st }}$ International Casuarina Workshop. Melbourne, Australia: CSIRO; 1983. p. 55-7.

4. Midgley SJ, Byron RN, Chandler FC, Ha Huy Thinh, Tran Vo Hung Son, Hoang Hong Hanh, Do plants need passports? A socio-economic study of the role of the exotic tree and other plant species in Quang Tri province, Vietnam. Canberra, Australia: CSIRO; 1997.

5. Shafi Thompson T, Alen Paiva, Greeshma G, Mohan, Jincy Das, Arys Suresh, et al. Phytochemical studies on C. equisetifolia and investigation of its effect against the oral pathogen. Int J Pharma Sci Res 2012;90:24.

6. Kishore DV, Rahman R. Spasmolytic activity of Casuarina equisetifolia bark extract. Int J Pharm Sci Res 2012;3:1452-6.

7. Singleton VL, Orthofer R, Lamuela-Raventos RM. Analysis of total phenols and other oxidation substrates and antioxidants by means of Folin-Ciocalteu reagent. Methods Enzymol 1999;299:152-78.

8. Chang C, Yang M, Wen H, Chern J. Estimation of total flavonoid content in propolis by two complementary colourimetric methods. J Food Drug Anal 2002;10:178-82.

9. Sadasivam S, Manickam A. Biochemical methods for agricultural sciences. Wiley eastern limited, New delhi; 1992. p. 6-7, 188-9.

10. Tejavathi DH, Jayashree DR. Phytochemical screening of selected medicinal herbs inoculated with arbuscular mycorrhizal fungi. Int J Biol Pharm Allied Sci 2013;2:2090-106.

11. Blios MS. Antioxidant determinations by the use of a stable free radical. Nature 1958;181:1199-200.

12. Ruch RJ, Cheng SJ, Klaunig JE. Prevention of cytotoxicity and inhibition of intercellular communication by antioxidant catechins isolated from Chinese green tea. Carcinogenesis 1989;10:1003-8.

13. Oyaizu M. Studies on products of browning reaction: antioxidative activities of products of browning reaction prepared from glucosamine. Japan J Nutr 1986;44:307-14.

14. Smirnoff N, Cumbes QJ. Hydroxyl radical scavenging activity of compatible solutes. Phytochemistry 1989;24:1057-60.

15. Pilar Prieto, Manuel Pineda, Miguel Aguilar. Spectrophotometric quantitation of antioxidant capacity through the formation of a phosphomolybdenum complex: specific application to the determination of vitamin E. Anal Biochem 1999;269:337-41.

16. Mizushima Y, Kobayashi M. Interaction of anti-inflammatory drugs with serum proteins, especially with some biologically active proteins. J Pharma Pharmacol 1968;20:169-74.

17. Nusrat J Bristy, Mohammad F Islam, Sharif M Anisuzzaman, Mohammad N Alam. Antioxidant activity of the water extracts of leaves, root barks, barks of Casuarina littorea. Aust J Basic Appl Sci 2014;8:419-26.

18. Baravkar A, Kale A, RN Patil, Sawant SD. Pharmaceutical and biological evaluation of formulated cream of methanolic extract of Accacia nilotica. Res J Pharm Technol 2008;1:481-3.

19. S Kumar, A Mishra, AK Pandey. Antioxidant mediated protective effect of Parthenium hysterophorus against oxidative damage using in vitro models. BMC Complementary Alternative Medicine 2013;13:120.

20. S Kumar, AK Pandey. Phenolic content, reducing power and membrane protective activities of Solanum xanthocarpum root extracts. Vegetos 2013;26:301-7.

21. Shahrzad S, Aoyagi K, Winter A, Koyama A, Bitsch I. Pharmacokinetics of gallic acid and its relative bioavailability from tea in healthy humans. J Nut 2001;131:1207-10.

22. Park HH, Lee S, Son HY, Park SB, Kim MS, Choi EJ, et al. Flavonoids inhibit histamine release and expression of proinflammatory cytokines in mast cells. Arch Pharm Res 2008;31:1303-11.

23. RI Okoli, AA Turay, JK Mensah, AO Aigbe. Phytochemical and antimicrobial properties of four herbs from Edo State, Nigeria. Report Opinion 2009;1:67-73.

24. Yondu J, Dongsmo G, Marie C, Wabo J, Olivia T, Jules-Roger, Blaise M. In vitro antioxidant potential and phytochemical constituents of three Cameroonian medicinal plants. Pharmacol Online 2009;10:648-57.

25. Manisuthisakul P, Suttajit M, Pongsawatmanit R. Assesment of phenolic content and free radical scavenging capacity of some Thai indigenous plants. Food Chem 2007;100:1409-18.

26. Park HH, Lee S, Son HY, Park SB, Kim MS, Choi EJ. Flavonoids inhibit histamine release and expression of pro-inflammatory cytokinensis in mast cells. Arch Pharm Res 2008;31:1303-11.

27. Karamaæ MA, Kosiñska, Pegg RB. Comparison of radicalscavenging activities of selected phenolic acids. Pol J Food Nutr Sci 2005;2:165-70. 
28. Kaur S, Michael H, Arora S, Harkonen PL, Kumar S. The in vitro cytotoxic and apoptotic activity of Triphala-an Indian herbal drug. J Ethnopharm 2005;97:15-20.

29. Isosorbide Dinitrate/Mononitrate. The American Society of Health-System Pharmacists; 2016.

30. Hecker M, Hollert H, Cooper R, Vinggaard AM, Akahori Y, Murphy M, et al. The OECD validation program of the H295R Steroidogenesis Assay for the identification of in vitro inhibitors and inducers of testosterone and estradiol production. Phase 2: inter-laboratory pre-validation studies. Environ Sci Pollut Res 2007;14:23-30.

31. Alok Prakash, Suneetha V. Punica granatum (Pomegranate) rind extract as a potent substitute for L-ascorbic acid with respect to the antioxidant activity. Res J Pharm Biol Chem Sci 2014;2:597-603.

32. Nehad M Gumgumjee, Abdulrahman S Hajar. Antimicrobial efficacy of Casuarina equisetifolia extracts aginst some pathogenic microorganism, Journal of Medicinal Plants Research 2012;6:5819-25.

33. Moreno S, Scheyer T, Romano C, Vojnov A. Antioxidant and antimicrobial activities of rosemary extracts linked to their polyphenol composition. Free Radical Res 2006;40:223-31.

34. Kamalakannan P, Kavitha R, Elamathi R, Deepa T, Sridhar S. Study of the phytochemical and antimicrobial potential of methanol and aqueous extracts of aerial parts of Elephantopus scaber L. Int J Curr Pharm Res 2012;4:18-21.

35. Sharma BL, Daulat Singh, Santosh Sharma K, Afzal Hashmi, Arjun Singh, Anil Bansal. Studies on some primary metabolite's extraction and Quantification in different plant parts of selected cassia species. Asian J Pharm Clin Res 2013;6:309-14.

36. AN Aher, SC Pal, SK Yadav, UK Patil, S Bhattacharya. Antioxidant activity of isolated phytoconstituents from Casuarina equisetifolia frost (Casuarinaceae). J Plant Sci 2009;4:15-20.

37. Lucio M, Nunes C, Gaspar D, Ferreira H, Lima JLFC, Reis S. Antioxidant activity of vitamin $\mathrm{E}$ and Trolox: understanding of the factors that govern lipid peroxidation studies in vitro. Food Biophysics 2009;4:312-20.

38. Gulcin IS, Bey Demir HA, Alici M, Buyukokuroglu ME. In vitro antioxidant proper tog morphine. Pharmocologic used to manage parasitic diseases. Research 2004;2:59-66.
39. Cotelle N. Role of flavonoids in oxidative stress. Curr Tropics Med Chem 2001;1:569-90.

40. B Fuhrman, S Buch, J Vaya. Licorice extract and its major polyphenol glabridin protect low-density lipoprotein against lipid peroxidation: in vitro and ex vivo studies in humans and in atherosclerotic apolipoprotein E-deficient mice. Am J Clin Nutr 1997;66:267-75.

41. Ryszard Amarowicz. Tannins: the new natural antioxidants? Eur J Lipid Sci Technol 2007;109:549-51.

42. M Karamac, A Kosinska, R Amarowicz. Chelating of Fe(II), $\mathrm{Zn}(\mathrm{II})$ and $\mathrm{Cu}$ (II) by tannin fractions separated from hazelnuts, walnuts and almonds. Bromat Chem Toksykol 2006;10:257-60.

43. YJ Zhang, DL DeWitt, S Murugesan, MG Nair. Novel lipiperoxidation and cyclooxygenase inhibitory tannins from Picrorhiza kurrora seeds. Chem Biodiver 2004;1:426-41.

44. Grassmann J. Terpenoids as plant antioxidants. Vitam Horm 2005;72:505-35.

45. Yousra Shafiq, Baqir Shyum Naqvi, Ghazala H Rizwani, Muhammed Usman, Barkat Ali Shah, Muhammad Aslam, et al. the Anti-acne activity of Casuarina equisetifolia bark extract: a randomized clinical trial. Bangladesh J Pharmacol 2014;9:337-41.

46. Middleton EJr, Kandaswami C, Theoradies TC. The effects of plant flavonoids on mammalian cells: Implications for inflammation, heart disease, and cancer. Pharmacol Rev 2000;52:673-751.

47. Rathee P, Chaudhary H, Rathee S, Rathee D, Kumar V, Kohli K. Mechanism of action of flavonoids as anti-inflammatory agents. Inflamm Allergy Drug Targets 2009;8:229-35.

48. Gonzalez R, Ballester I, Lopez-Posadas R, Suarez MD, Zarzuelo A, Martinez-Augustin 0 , et al. Effects of flavonoids and other polyphenols on inflammation. Crit Rev Food Sci Nutr 2011;51:331-62.

49. Sreedevi1 K, Vijayalakshmi R, Venkateswari. Phytochemical evaluation of Punica granatum L. leaf extract. Int J Curr Pharm Res 2017;9:14-8.

50. Dependra Chamlagai, Bisu Singh. Study of in vitro antiinflammatory activity of ethnomedicinal plants of sikkim Viscum articulatum and Acorus calamus. Asian J Pharm Clin Res 2016;9:119-22. 